DOI: $10.17951 /$ rh.2018.46.203-218

\author{
Wiesław Caban \\ (Uniwersytet Jana Kochanowskiego w Kielcach) \\ https://orcid.org/0000-0002-3695-8259
}

\author{
Swietłana Mulina \\ (Państwowy Uniwersytet im. Fiodora Dostojewskiego w Omsku) \\ https://orcid.org/0000-0002-4149-0291
}

\title{
Zesłańcy postyczniowi w Kurganie. Sprawa Towarzystwa Pomocy Wzajemnej*
}

Polish Exiles in Kurgan. The Case of the Society for Mutual Assistance

\section{STRESZCZENIE}

Po upadku powstania styczniowego do Kurganu zesłano stu kilkudziesięciu młodych Polaków, głównie z Litwy. Władze miasta nie były w stanie zapewnić utrzymania dla tylu osób. Większość zesłanych nie otrzymywała zapomóg rządowych. W niezłym położeniu byli jedynie ci, którzy otrzymywali pieniądze od rodziny. W tej sytuacji Polacy założyli „związek przeciw głodowi i chłodowi”, który później przybrał nazwę Towarzystwa Pomocy Wzajemnej. Głównym celem było zbieranie środków pieniężnych, by można było wspomóc tych, którzy z domu nie otrzymywali żadnej pomocy materialnej. Towarzystwo Pomocy Wzajemnej miało swój regulamin, który zakazywał m.in. picia alkoholu, gry w karty, oddawania się jakimkolwiek hazardom, nawiązywania kontaktów z rozwiązłymi kobietami i co najważniejsze zawierania małżeństw z Rosjankami.

Na działalność Towarzystwa Pomocy Wzajemnej z pobłażliwością patrzył horodniczy Kurganu Michaił Awenirowicz Karpiński, gdyż uznał, że zesłańcy skupieni w organizacji będą przestrzegać przyjętego regulaminu i tym samym nie będzie dochodzić do żadnych nieporozumień między Polakami a mieszkańcami Kurganu. Wydaje się, że na takie stanowisko horodniczego mógł mieć wpływ 27-letni Michał Żaba, absolwent Wydziału Medycznego Uniwersytetu Moskiewskiego.

* Artykuł został przygotowany w ramach projektu NPRH Umowa nr 0098/NPRH3/ H12/82/2014 pt.: „Polscy zesłańcy na Syberii Zachodniej w drugiej połowie XVIII wieku XIX wieku w oczach Rosjan i ludności syberyjskiej". 
Spośród mieszkańców Kurganu zaczęto pisać najpierw donosy na M. Awenirowicza Karpińskiego, że pobłażliwie traktuje Polaków, a następnie na gubernatora tobolskiego Aleksandra Iwanowicza Despot-Zenowicza. W końcu sprawą zainteresowano generał-gubernatora zachodniej Syberii Aleksandra Piotrowicza Chruszczowa. W 1867 r. rozpoczęło się śledztwo. Spośród zesłańców najbardziej ucierpiał Michał Żaba, który został uznany nie tylko za winnego powołania do życia Towarzystwa Pomocy Wzajemnej, ale także za to, że takie organizacje próbował zakładać w Iszymiu czy Jałturowsku. Jednym słowem, M. Żaba został posądzony o przygotowywanie spisku przeciw istniejącemu porządkowi w Rosji.

Historycy radzieccy w latach sześćdziesiątych XX w. sprawę śledztwa kurgańskiego potraktowali jako przykład polsko-rosyjskiej współpracy rewolucyjnej na Syberii. Naszym zdaniem powstałe Towarzystwo Pomocy Wzajemnej należałoby uznać za próbę odrodzenia „Ogółów” z czasów zsyłki z okresu międzypowstaniowego.

Słowa kluczowe: Syberia, Polacy, zesłańcy, Kurgan

Sprawą zesłańców postyczniowych do miasta Kurgan (gubernia tobolska) zainteresował się już w latach sześćdziesiątych XX w. radziecki historyk Siemion Fedorowicz Kowal, ale głównie w aspekcie tzw. polsko-rosyjskiej współpracy rewolucyjnej ${ }^{1}$. Otóż w Gosudarstwiennym Istoriczeskim Archiwie Omskoj Obłasti znajdują się trzy tomy akt zatytułowane jako tzw. „dieło Karpinskogo”2. Wyjaśnijmy od razu, że M. Awenirowicz Karpiński był horodniczym okręgu kurgańskiego w latach 1864-1866 i w 1866 r. zostało przeciwko niemu wszczęte śledztwo, gdyż jakoby współpracował z polskimi zesłańcami, którzy z kolei mieli założyć tajną organizację rewolucyjną. Sprawa kurgańska wpisywała się więc w obowiązujący wtedy nurt badań nad współpracą rewolucjonistów polskich i rosyjskich ${ }^{3}$.

W trzech tomach akt znajdują się listy polskich zesłańców z lat 18641866. W dużej mierze nieocenzurowane, bo do ich przesyłania wykorzystano różne kontakty osobiste, głównie z rosyjskimi kupcami i urzędni-

1 С.Ф. Коваль, За правду и волю. К столетию восттания политических ссыльных в Сибири в 1866 г. Иркутск 1966; idem, Революиионная деятельность польских политических ссыльных в Сибири в 60-е гг. ХІХ в., w: Экономическое и общественно-политическое развитие Сибири в 1861-1917 г2., Новосибирск 1965, s. 123-132.

2 Госсударственный Исторический Архив Омской Области [dalej: ГИАОО], Фонд 3 [dalej: Ф.], Опис 6 [dalej: Оп.], Дело [dalej: Д.] 7921, t. 1-3.

3 Po zmianach politycznych 1990 r., zarówno historycy polscy, jak i rosyjscy do wielu ustaleń dotyczących tzw. współpracy rewolucyjnej odnoszą się ze sporym dystansem. W naszym odczuciu wydaje się to czasami niepotrzebne. Niewątpliwie część historyków rosyjskich, jak i polskich, szukała dowodów na potwierdzenie tej tezy. Pewne fakty zostały nadinterpretowane. Ale też trzeba pamiętać, że historyk, studiując akta śledcze, które czasami były zdekompletowane, w jakiś sposób przyjmował ich narrację. Nie ulega wątpliwości, że taka współpraca istniała, natomiast oddzielną kwestią jest jej skala. Te sprawy wymagają ponownych badań. Niemniej jednak nie można zarzucać S.F. Kowalowi, że doszukał się funkcjonowania tajnej organizacji rewolucyjnej wśród Polaków zesłanych do Kurganu. 
kami. W wyniku wszczętego śledztwa listy zostały zarekwirowane przez policję i dla potrzeb tegoż śledztwa przetłumaczono je na język rosyjski. W sumie zachowało się nieco ponad 100 listów w języku polskim i tyleż ich odpowiedników w języku rosyjskim ${ }^{4}$. Oprócz listów znajduje się tu część dokumentów śledczych, które powstały w wyniku przesłuchań pol-

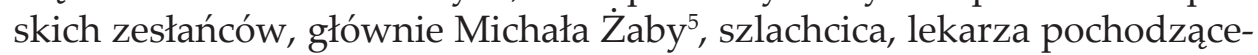
go z guberni wileńskiej i horodniczego Kurganu Michaiła Awenirowicza Karpińskiego ${ }^{6}$.

Uczestnicy powstania styczniowego trafiali na zesłanie do Kurganu, poczynając od kwietnia $1864 \mathrm{r}$. Na podstawie przeprowadzonej dotychczas lektury listów zesłańców można sądzić, że byli to głównie mieszkańcy guberni wileńskiej i w ogóle z tzw. ziem zabranych, ale niektórzy pochodzili też z Królestwa Polskiego. W kwietniu 1864 r. było tu 17 Polaków, w sierpniu 77, w końcu grudnia 1865 r. już 120, a w czerwcu 1866 r. aż

4 Listy te były już przedmiotem zainteresowania S.A. Muliny. Por.: C.A. Перминова (С.А. Мулина), Взаимоотношения польских ссыльных с жителями Сибири (по матери алам переписки М.О. Жаба), w: Polska a Syberia. Spotkanie dwóch światów. Materiały z konferencji naukowej, red. M. Blomberg, Łodź 2001, s. 155-165; С.А. Мулина, Мигранты поневоле: адаптация ссыльных участников Польского восстания 1863 года в Западной Сибири, Санкт Петербург 2012; еаdеm, Контакты ссыльных участников восстания 1863 года с исторической родиной (на примере корреспонденциии Михаила Жабы и Эдуарда Радванckozo), w: Polskie dziewiętnastowieczne pamiętniki i listy z Ziem Zabranych - rola i miejsce w badaniach historycznych, red. W. Caban, L. Michalska-Bracha, Warszawa 2017, s. 361-371.

5 Michał Żaba, urodzony w 1842 r. w rodzinie szlacheckiej w powiecie dziśnieńskim (gubernia wileńska). Jego ojciec Józef, właściciel dóbr ziemskich Sza w tymże powiecie, posiadał księgozbiór książek pochodzących z XVII w. do połowy 1863 r. Po ukończeniu Instytutu Szlacheckiego w Wilnie wstąpił w 1857 r. na Wydział Lekarski Uniwersytetu Moskiewskiego. Stopień lekarza otrzymał w 1862 r. Brał udział w powstaniu styczniowym. Decyzją sądu został pozbawiony praw stanu i zesłany na zamieszkanie do Kurganu, dokąd przybył w $1864 \mathrm{r}$. Zajmował tu posadę ekonoma w więziennym lazarecie. Tu zaangażował się w działania na rzecz utrzymania właściwych relacji między Polakami zesłanymi do Kurganu. Szczególną troskę wykazał o tych zesłańców, którzy byli pozbawieni jakichkolwiek środków do życia. Rozpoczęło się śledztwo, a M. Żaba został uznany za jednego z głównych winowajców zorganizowania Towarzystwa Pomocy Wzajemnej (ГИАОО, Ф. 3, Оп. 4, Д. 6293; Ф. 3, Оп. 6, Д. 9079). Odtworzenie zesłańczych losów M. Żaby jest trudne. Wiadomo, że ostatecznie wrócił do rodzinnej miejscowości i był uznanym lekarzem. Zmarł w 1890 r. Króciutki nekrolog ukazał się w czasopiśmie „Kraj” 1890, nr 17, s. 19. Dziękujemy p. prof. dr hab. Jolancie Sikorskiej-Kuleszy za umożliwienie nam dotarcia do tej informacji.

6 Michaił Awenirowicz Karpiński, po ukończeniu szkoły powiatowej wstąpił na służbę rządową w 1840 r. Od 1861 r. pracował w kurgańskim sądzie ziemskim. Od października 1864 r. był horodniczym Kurganu. W związku z prowadzonym śledztwem w sprawie spisku Polaków, którym niewątpliwie sprzyjał, został przeniesiony na stanowisko horodniczego do Tiumeni. Następnie pracował na posadach rządowych w Omsku. Zmarł w 1895 r. Государственное учереждение Тюменской Области „Государственный архив в городе Тобольске" [dalej: ГУТО ГАТ], Ф. И152, Оп. 34, Д. 516). 
160 osób. Powiadamy, że aż 160 polskich „miatieżników”, bo sam Kurgan w tym czasie liczył ok. 3,6 tys. mieszkańców. Polacy stanowili tu zatem $4 \%$ społeczności tego miasteczka. Czy to dużo, czy mało? Wydaje się, że to jednak duża grupa i dla władz miasta oraz tamtejszej społeczności musiała stanowić spory problem. Miasto bowiem było biedne i nie było w stanie w żaden sposób zapewnić zasadniczej grupie zatrudnienia na posadach rządowych czy u prywatnych przedsiębiorców.

Warto nadmienić, że polscy zesłańcy znaleźli się w Kurganie już na początku lat trzydziestych XIX w. Chodzi o osoby, które, z jednej strony, związały się z ruchem spiskowym, a z drugiej, byli to żołnierze powstania listopadowego wzięci do rosyjskiej niewoli. Zdaniem historyka-krajoznawcy Jekateriny Władimirowny Tierszukowoj, liczba Polaków była na tyle duża, że można mówić o polskiej diasporze. Polacy mieli tu przebywać według zasad ustalonych przez siebie. Pielęgnowali rodzime tradycje. Mieli możliwości, choć nieregularnie, spełniania posług religijnych. Często na ulicach Kurganu słyszało się polskie pieśni. Uroczyście obchodzono rocznicę ustanowienia Konstytucji 3 maja. Utrzymywano ścisłe kontakty z zesłanymi tu dekabrystami ${ }^{7}$.

Wróćmy do zarekwirowanych przez policję listów, bowiem stanowią one interesujące źródło do dziejów polskiej diaspory w Kurganie. Przede wszystkim na ich podstawie można ustalić bolączki zesłanych. Pierwsza, najważniejszą rzeczą było nawiązanie kontaktów z rodziną co mogło się w zasadzie odbywać tylko przy wykorzystaniu poczty. Listy nie dochodziły regularnie, a brak wiadomości od rodziny doprowadzał niejednego zesłańca do załamania psychicznego. Zresztą do podobnych sytuacji dochodziło i po drugiej stronie, czyli rodziców oraz krewnych, którzy pozostali w kraju.

Wspomniany już wcześniej Michał Żaba po przybyciu w kwietniu 1864 r. do Kurganu postanowił pisać listy do rodziców co 2-3 tygodnie,

7 Е.В. Тершукова. Ссыльные поляки в г. Кургане в первой половине ХІХ века, httр:// www.kurgangen.ru/local-finding/Poles\%20in\%20Zaurali/Poland\%20in\%20Kurgan $\% 20$ III/ [dostęp: 13 I 2017]. Z tegoż opracowania, opartego na materiałach znajdujących się w archiwum kurgańskiego obwodu, wynikałoby, że w latach czterdziestych XIX w. w Kurganie mogło być do 20 Polaków. Jedną z głównych ról odgrywał tam Julian Rościszewski (1812-1871). Uczestniczył on w powstaniu listopadowym, a do Kurganu został zesłany za to, że udzielał pomocy Arturowi Zawiszy i jego grupie partyzanckiej w $1833 \mathrm{r}$. Zob. W. Śliwowska, Zesłańcy polscy w Imperium Rosyjskim w pierwszej połowie XIX wieku, Warszawa 1998, s. 513-514. Ostatnio na temat relacji między Polakami zesłanymi do Kurganu a dekabrystami zabrał głos F. Nowiński, Dekabryści z Syberii Zachodniej w literaturze rosyjskiej i polskiej, relacje z Polakami, w: Польские ссыльные в Сивири во второй половине XVIII - начале XX века в восприятии российской администрациии, переселенцев и коренньх народов Сибири. Сборник научных трудов, red. С.А. Мулина, Омск 2015, s. 46-48. 
licząc, że w takim też tempie będą przychodzić odpowiedzi. Mylił się bardzo. Wreszcie w czerwcu tegoż roku napisał do rodziców: „Jutro trzeci miesiąc mego pobytu w Kurganie upływa, a dotychczas nie otrzymałem od Was ani litery, powodem tego musi być niewiedza może Wasza o miejscu mego pobytu i powture [sic!], iż może być listy moje pisane z Kurhanu nie doszły do Was". Pierwszy list M. Żaba otrzymał od rodziców dopiero w połowie lipca $1864 \mathrm{r}$. i wywołał on u niego silne wzruszenia ${ }^{8}$. Następne też przychodziły z ogromnym opóźnieniem. A w ogóle w ciągu 2-letniego pobytu M. Żaby w Kurganie otrzymał on od rodziców zaledwie 3 listy.

Druga kwestia, która rzuca się w oczy w trakcie lektury listów - to nieustanne poszukiwania krewnych i znajomych rozesłanych przez Michaiła Murawjowa po całej Syberii. Skutki tych poszukiwań dawały skromne efekty, a było to bardzo ważne, bowiem po ustaleniu adresu można było nawiązać jaką taką korespondencję. Dzielenie się swoimi troskami z krewnymi i bliskimi, z którymi chodziło się do szkoły czy uczęszczało na studia, umacniało zesłańca na duchu.

Ale jest i kolejny aspekt lektury listów, zwłaszcza tych pisanych przez krewnych, którzy pozostali na Litwie. Otóż pozwalają one lepiej zrozumieć, czym były represje M. Murawjowa wobec polskiej szlachty na Litwie, zwłaszcza tej mniej zamożnej. Urzędowe raporty o konfiskatach polskich majątków mają swoją wymowę, ale gdy czyta się korespondencję przykładowo między Edwardem Radwańskim ${ }^{9}$ a jego żoną Anielą że dla uszycia koszul i innego odzienia sprzedała krowę, a on tych rzeczy nie otrzymał i podejrzewał żonę o fałszywe zachowanie, to wtedy lepiej ro-

8 Pisał on: „List Wasz od 7 Marca otrzymałem ledwo 16 Lipca, napełnił on mnie i radością i smutkiem, dowiedziałem się z niego choć tyle przynajmniej, żeście żywi, dzięki Bogu i za to, czytając Wasze wyrazy jeszcze głębiej uczułem to oddalenie od Was i strony rodzinnej, kędy często przenoszę się wyobraźnią i odnawiam w pamięci owe błogie chwile niegdyś tam spędzane, kiedyż nastąpi ta chwila, gdy marzenie moje ujrzę urzeczywistnione. Bogu to tylko wiedzieć, dla mnie teraz dosyć jest tej pociechy, że mam pewność żeście żywi, i że wiecie gdzie się obraca Wasz syn, przynajmniej nadal mamy zapewnioną choć listowną rozmowę".

9 Edward Radwański, urodzony w 1830 r., szlachcic z powiatu trockiego (gubernia wileńska), za udział w powstaniu został pozbawiony praw stanu i zesłany na osiedlenie do Kurganu. Prawdopodobnie Edward w wyniku jednej z amnestii wyniósł się z Kurganu. Pozostał tutaj jego brat Jan, z którym Edward nie utrzymywał zbyt bliskich kontaktów. Jan ożenił się z Rosjanka, a dzieci z tego małżeństwa zachowały wiarę katolicką i znały język polski. Radwańscy prowadzili duże gospodarstwo, w którym zatrudniali kilka osób, prawdopodobnie polskich zesłańców. Na Syberii znalazł się jeszcze trzeci brat Konstantyn, którego zesłano na katorgę do Nerczyńska. Po odbyciu kary, schorowany, chciał zamieszkać w Kurganie przy braciach, by otoczyli go opieką. Otrzymał pozwolenie i został zatrudniony w składzie win. ГУТО ГАТ, Ф. И152, Оп. 7, Д. 157; Оп. 36, Д. 178), http://www.kurgangen.ru/photos/thumbnails.php?album=290 [dostęp: 10 VI 2017]. 
zumie się tragiczną sytuację szlacheckiego polskiego zaścianka na Litwie, który tak mocno ucierpiał po powstaniu. Z kolei Józef Żaba, ojciec Michała, niemający żadnych środków na uszycie zimowego palta i przesłanie go synowi, by chronić go przed syberyjskim zimnem, postanowił wysłać swoje stare palto.

Z korespondencji, co jest oczywiste, dowiadujemy się o sytuacji materialnej zesłańców, relacjach między nimi i stosunkach z mieszkańcami Kurganu. W zasadniczej części listów pisanych przez rodziców i krewnych z Litwy do swych bliskich zesłanych do Kurganu wynika wyraźnie, że poziom wykształcenia sporej części szlachty na Wileńszczyźnie był niski. W wielu z tych listów trudno doszukać się składni, nie mówiąc już o poprawnej pisowni ${ }^{10}$.

Czas, by nieco miejsca poświęcić sprawie Towarzystwa Pomocy Wzajemnej. Jak już wspomniano, w Kurganie znalazło się w pewnym momencie ok. 160 zesłańców. Jedna wspólna cecha tej zbiorowości to fakt, że stanowili ją młodzi, dwudziestoparoletni mężczyźni. Poza tym było to środowisko o dużym zróżnicowaniu, zarówno jeśli chodzi o pochodzenie społeczne, jak i wykształcenie. Grupa, jak powiadano w XIX w., „ukształconych" była nieliczna. Nadto trzeba pamiętać, że nie każdy „leśny” patriota był porządnym człowiekiem. W oddziałach powstańczych było wiele osób określanych jako „lichego charakteru”, które znalazłszy się na zesłaniu, dość często dopuszczały się kryminalnych przestępstw, działając na własną rękę lub we współpracy z rosyjskimi kryminalistami. Do tego dochodziła trudna sytuacja materialna. Osoby, które nie zostały zaopatrzone przez rodzinę $\mathrm{w}$ odpowiednie kwoty pieniężne na drogę, miały w pierwszym okresie pobytu w Kurganie ogromne trudności z utrzymaniem się. Władze co prawda zapewniały wypłatę zapomóg na zakup żywności, tzw. kormowych dienieg, ale były z tym duże problemy, bowiem urzędnicy zwyczajnie nie mieli pojęcia, jak się do tego zabrać, a kiedy już zorientowali się, że wypłata kormowych dienieg jest ich obowiązkiem, to nie zawsze postępowali według obowiązujących przepisów. I nie wynikało to z ich złej woli, ale z nieuctwa i pijaństwa. W takiej sytuacji wśród „ukształconych" zesłańców pojawił się pomysł założenia wspólnej kasy, by w ten sposób obdzielić wszystkich takimi środkami finansowymi, które umożliwiłyby im przeżycie najtrudniejszego okresu. Inicjatorem „związku przeciw głodowi i chłodowi" był właśnie Michał Żaba.

10 Wspomniano, że listy dla potrzeb śledztwa były przetłumaczone na język rosyjski. Trzeba wyrazić słowa uznania wobec tłumacza, bo on sam niejednokrotnie musiał odgadnać, co autor miał na myśli, a dopiero później tłumaczył tę myśl na język rosyjski. Nie zawsze tłumaczowi udało się w pełni oddać sens listu, który tak nieporadnie został napisany. 
O tym, że w Kurganie polscy zesłańcy stanowili w jakiś sposób zorganizowaną grupę dowiedział się w wyniku donosu w kwietniu $1865 \mathrm{r}$. gubernator tobolski, Polak z pochodzenia, Aleksandr Iwanowicz Despot-Zenowicz i zwrócił uwagę horodniczemu kurgańskiemu, że jest to niedopuszczalne ${ }^{11}$. Horodniczy, zamiast przestraszyć się gubernatora, pochwalił się przed nim swymi metodami postępowania wobec zesłańców, gdyż uznał to za swój sukces. Horodniczy Awenirowicz Karpiński nie widział bowiem niczego zdrożnego w tym, że wśród zesłańców powstało stowarzyszenie, które „ceni[ło] sobie swój narodowy charakter i spokój publiczny"12. Tymczasem A. Despot-Zenowicz był wyraźnie poirytowany, że M. Awenirowicz Karpiński popierał oddzielne polskie, narodowe stowarzyszenie, a zarazem odmawiał „narodowego honoru Rosjanom z Kurhanu"13. Zagroził mu więc zastosowaniem surowszej kary, lecz najprawdopodobniej nie wyciągnął wobec niego żadnych konsekwencji. Do końca grudnia 1865 r. M. Awenirowicz Karpiński pozostawał na stanowisku horodniczego, mimo że do A. Despot-Zenowicza napływały donosy na jego postępowanie wobec Polaków, m.in. o tym, że w służbach policyjnych i pożarniczych zatrudniał on Polaków za odpowiednim wynagrodzeniem. Fakty te później się potwierdziły, co zostanie omówione w dalszej części artykułu.

Ostatecznie w1867 r. M. Awenirowicz Karpiński został przeniesiony z Kurganu do Tiumeni. W tymże samym roku funkcje gubernatora tobolskiego przestał sprawować A. Despot-Zenowicz. Czy był to zbieg okoliczności, czy też skutek tego, że gubernator tobolski nie zareagował zdecydowanie na postępowanie horodniczego? Na tak postawione pytanie trudno odpowiedzieć jednoznacznie. Wiadomo, że na przyzwolenie przez M. Awenirowicza Karpińskiego na działalność organizacji, która, jak później ustalono, przekształciła się w Towarzystwo Pomocy Wzajemnej, został skierowany donos do Aleksandra Pietrowicza Chruszczowa,

11 W tajnym piśmie skierowanym przez A. Despot-Zenowicza do horodniczego Awenirowicza Karpińskiego z 8 kwietnia 1865 r. czytamy: „Dotarło do mojej wiadomości, że w mieście Kurgan przestępcy polityczni mieli zebranie w celu omówienia postępku jednego z zesłańców, należących do grupy tych przestępców. Jeśli świadectwa te są uzasadnione, to ja uważam za konieczne znowu surowo potwierdzić Wielmożnemu Panu, że zebrania przestępców politycznych, w jakiej by one nie przebiegały formie oraz jakim celem się nie tłumaczyły, są niedopuszczalne i że w przypadkach złamania tego, wobec winnych będą podjęte surowsze środki". ГИАОО, Ф. 3, Оп. 6, Д. 7921, Аисток [dalej: 1.] 44). Otóż zebranie to odbyło się w związku z dokonaniem przestępstwa kryminalnego przez jednego z zesłańców.

12 ГИАОО, Ф. 3, Оп. 6, Д. 7921, А. 47-47 об.

13 Ibidem. 
generała-gubernatora Syberii Zachodniej w latach 1866-1875 ${ }^{14}$. Skądinąd wiadomo też, że na A. Despot-Zenowicza wpływał do Petersburga, jak to określił Zbigniew Wójcik, "potok donosów” z różnych kręgów wojskowo-administracyjnych, zwłaszcza spośród zwolnionych przez niego osób $\mathrm{z}$ odpowiednich stanowisk ${ }^{15}$. Być może wszystko złożyło się na to, że odwołano i A. Despot-Zenowicza, i M. Awenirowicza Karpińskiego, a duży mógł być w tym udział generała-gubernatora A. Chruszczowa.

Co zatem ustalono w śledztwie przeprowadzonym w $1867 \mathrm{r}$. z polecenia generała-gubernatora Syberii Zachodniej? Otóż okazało się, że „związek przeciw głodowi i chłodowi" przekształcił się w Towarzystwo Pomocy Wzajemnej, które posiadało swój regulamin. Przesłuchiwany na tę okoliczność M. Żaba twierdził, że spisanego regulaminu nie było, że obowiązywały tylko ustne ustalenia, „które się same ułożyły”. Nie sądzimy, by władze zadowoliły się tymi zapewnieniami, zwłaszcza że z innej korespondencji kierowanej do M. Żaby jasno wynika, iż był proszony o przesłanie regulaminu Towarzystwa Pomocy Wzajemnej do Iszymia, ponieważ także i tam chciano założyć podobną organizację ${ }^{16}$.

Regulamin zakładał m.in., że Polacy mają przede wszystkim nie pić alkoholu, nie grać w karty i nie oddawać się innym grom hazardowym, nie nawiązywać kontaktów z rozwiązłymi kobietami oraz nie zawierać małżeństw z prawosławnymi. Była też mowa o wzajemnej pomocy materialnej. Zarząd organizacji rezerwował sobie prawo do rozstrzygania wszelkich sporów, do jakich mogłoby ewentualnie dochodzić pomiędzy zesłańcami.

Regulamin mieli podpisać wszyscy zesłańcy. Nie wszyscy jednak wyrażali na to zgodę i niektórych należało do podpisu przymusić, a kilka osób, które zaczęły się awanturować, musiało opuścić Kurgan przy aprobacie horodniczego Awenirowicza Karpińskiego. Jednych wysłano do Berezowa, innych do Obdorska.

Pełną wiedzę o funkcjonowaniu Towarzystwa Pomocy Wzajemnej miał horodniczy Awenirowicz Karpiński. Uważał on bowiem, że polscy zesłańcy skupieni w organizacji będą przestrzegać przyjętego regulaminu

14 Generał A.P. Chruszczow (1806-1875), w czasie powstania styczniowego tłumił działania polskie w Lubelskiem. Od połowy 1864 r. był pomocnikiem Michaiła Nikołajewicza Murawjowa, grodzieńskiego, mińskiego i wileńskiego generała-gubernatora (1863-1865).

15 Z. Wójcik, Aleksander Despota(!)-Zenowicz w oczach zestańców, w: Польские ссыльные в Сибири во второй половине XVIII-начале XX века в восприятии российской администраиии, переселенцев и коренных народов Сибири. Сборник научных трудов, Омск 2015, s. 130; А.В Ремнев, Тоболский губернатор А.И. Деспот-Зенович, w: Таре 400 лет, ч. 1, Омск 1994, s. 22-27.

16 ГИАОО, Ф. 3, Оп. 6, Д. 7921, Л. 501-503. Z dużym prawdopodobieństwem można założyć, że ów regulamin został wysłany również do Jałutorowska, Omska, Szdryńska i Tobolska. Czy takie towarzystwa tam powstały - na to już trudno odpowiedzieć. 
i tym samym nie będzie dochodziło do jakichkolwiek konfliktów czy sporów między Polakami a mieszkańcami Kurganu. W swoich zeznaniach przyznał się, że pomógł wydalić z miasta tych Polaków, którzy dopuszczali się przestępstw kryminalnych. Potwierdził też, że zatrudniał Polaków $\mathrm{w}$ policji ${ }^{17} \mathrm{i} \mathrm{w}$ służbach pożarniczych za wynagrodzeniem, nie widząc w tym niczego zdrożnego, bowiem miejscowi policjanci czy strażacy byli kompletnymi pijanicami, a na niego jako horodniczego spadała odpowiedzialność za utrzymanie spokoju w mieście, w którym przed objęciem przez niego stanowiska dochodziło do różnego rodzaju incydentów, w tym podpaleń.

W regulaminie, jak wspomniano, zapisano, że Polacy nie będą nawiązywać kontaktów z kobietami rozwiązłymi i nie będą zawierać małżeństw z prawosławnymi. Nie podporządkował się temu tylko jeden zesłaniec, a mianowicie Albert Pliskowski. Niestety, na tym etapie badań na ten temat zbyt wiele nie można powiedzieć. Wiadomo, że podjął on decyzję o poślubieniu pokojówki pani Farafontowej, żony asesora kolegialnego. Notabene owa kobieta, poparta przez niektórych urzędników, rozpoczęła akcję na rzecz umożliwienia zawierania małżeństw przez polskich zesłańców z rosyjskimi pokojówkami. A. Pliskowski był jedynym chętnym. Przejście na prawosławie i ożenek z pokojówką odradzał mu M. Żaba, albowiem jego zdaniem A. Pliskowski był człowiekiem niewykształconym i nieświadomym konsekwencji zmiany wyznania. Ponadto M. Żaba tłumaczył mu, że pokojówka pani Farafontowej nie prowadzi się zbyt dobrze. Warto podkreślić, że temu małżeństwu przeciwny był także sam horodniczy, który w śledztwie bardzo przekonująco tłumaczył się, że odradzał ożenek z Rosjanką gdyż obawiał się podstępności Polaków. A miała ona polegać na tym, że A. Pliskowski mógłby przekonać żonę do przejścia na katolicyzm, co prawdopodobnie skutkowałoby wychowywaniem potomstwa w wierze katolickiej. I dalej M. Awenirowicz Karpiński wywodził, że gdyby doszło do takiej sytuacji, to w mieście mogłyby pojawić się bunty przeciw niemu, dlatego że w wyniku jego błędnej decyzji ucierpiałby Kościół prawosławny.

17 Sprawa zatrudnienia Polaków w policji wymaga pewnego wyjaśnienia. Otóż M. Awenirowicz Karpiński nie zrobił tego samowolnie. Na ich zatrudnienie otrzymał pozwolenie od samego gubernatora. Ten takowe wydał, gdyż w momencie pojawienia się pierwszych zesłańców postyczniowych na Syberii władze nie wprowadziły takiego zakazu, bowiem miały świadomość słabości służb policyjnych i zezwoliły zatrudniać naczelnikom miast i gmin tzw. zaufanych Polaków w służbach policyjnych, głównie na posadach pisarzy. Po jakimś czasie wyszło rozporządzenie zabraniające zatrudniania Polaków w policji na stanowiskach pisarzy. Wtedy M. Awenirowicz Karpiński na polecenie A. Despot-Zenowicza zwolnił Polaków z tych posad. Dalej jednakże zatrudniał dwóch Polaków w Służbie Więziennej, bo nie było zakazu. ГИАОО, Ф. 3, Оп. 6, А. 7921, 1. 376-383 об. 
Wydaje się, że w tym przypadku pewien wpływ na takie stanowisko horodniczego mógł mieć M. Żaba, który był w dobrych kontaktach z Awenirowiczem Karpińskim i obydwaj mogli dojść do wniosku, że mieszane małżeństwa są niekorzystne, zarówno dla Polaków, jak i dla Rosjan. Ostatecznie jednak obydwaj nic nie uzyskali, bo Albert Pliskowski zdecydował się na przejście na prawosławie i przyjął imię Aleksander. Jakie były jego dalsze losy, trudno cokolwiek powiedzieć. Wiadomo natomiast, że grupa zesłańców w dniu ślubu doprowadziła do jakiegoś bliżej nieokreślonego zamieszania skierowanego przeciw nowożeńcom. Z kolei pani Farafontowa zaczęła oskarżać horodniczego, że ostentacyjnie popiera Polaków, bowiem z chwilą poślubienia przez A. Pliskowskiego jej pokojówki wstrzymał wypłacenie zapomogi na urządzenie gospodarstwa Polakowi, który ożenił się z Rosjanką. Tymczasem M. Awenirowicz Karpiński odpierał jej zarzuty, powołując się na tajną instrukcję od władz wyższych, która mu na to nie pozwalała. Trudno jednakże to jego zachowanie właściwie ocenić. Nie można wykluczyć, że miały na nie wpływ jego złe relacje z panią Farafontową i jej mężem, kolegialnym asesorem.

Innym przestępstwem, jakiego dopuściło się Towarzystwo Pomocy Wzajemnej, było prowadzenie sklepiku bez pozwolenia władz. Głównym inicjatorem tego przedsięwzięcia ponownie okazał się M. Żaba. W zeznaniu zaprzeczał, że to, co robił, można nazwać prowadzeniem sklepu. Otóż za zebrane od zesłańców pieniądze wraz pięcioma wspólnikami ${ }^{18}$ kupował najpotrzebniejsze towary po cenach hurtowych, a następnie sprzedawano je, nakładając pewną marżą. Zyski z marży pozwalały na rozszerzenie asortymentu w sklepiku, który prowadzony był w pomieszczeniach bliżej nieznanego Jurganowa, mieszkańca Kurganu. O jego działalności M. Żaba oficjalnie nie informował horodniczego, uznając, że nie ma takiej konieczności, ponieważ sklepik został założony tylko i wyłącznie dla potrzeb zesłańców.

Sklepik $\mathrm{w}$ pomieszczeniach u Jurganowa funkcjonował od grudnia 1864 r. do kwietnia 1865 r., a później założono podobny w domu Kozłowa. Ten działał już na nieco innych zasadach, a M. Żaba nie był, jak sam twierdził, zaangażowany $\mathrm{w}$ jego prowadzenie.

18 Byli to: 1) Joachim Drużbacki (1. 24), szlachcic z powiatu żytomierskiego (gubernia wołyńska). Do Kurganu przybył w czerwcu 1864 r., a następnie w 1866 r. z polecenia gubernatora tobolskiego został przeniesiony do Tiukały (obecnie Tiukalinsk), a stamtąd do Omska. Niewykluczone, że to przeniesienie było skutkiem jego zaangażowania w działalność Towarzystwa Pomocy Wzajemnej; 2) Ignacy Dubowik (1. 19), szlachcic z guberni mińskiej; 3) Dominik Karczewski (1. 28), szlachcic z guberni mohylewskiej; 4) Apolinary Kosecki (1. 42), szlachcic z guberni wileńskiej; 5) Roman Zborowski (1. 17), szlachcic z guberni kijowskiej. 
Zarząd Towarzystwa Pomocy Wzajemnej rozstrzygał spory, do jakich dochodziło między zesłańcami, jednak według śledczych było to poważnym przestępstwem, bowiem wkraczał on w kompetencje sędziowskie, które miały tylko władze Kurganu. O tych sprawach wiedział też horodniczy, który z kolei uznał, że lepiej nie angażować władz Kurganu w rozstrzyganie wewnętrznych sporów między Polakami, bo to mogłoby tylko doprowadzić do zaostrzenia sytuacji na linii zesłańcy - władze miasta. Zarząd wydał trzy takie wyroki. Pierwszy dotyczył Wincentego Brewczyńskiego, a dwa pozostałe Henryka Hryncewicza (Gryncewicza) i Aleksandra Korfa.

Największym echem odbiła się sprawa 27-letniego Wincentego Brewczyńskiego, mieszczanina z guberni warszawskiej. Otóż podczas Świąt Wielkanocnych naubliżał on żonie Leopolda Skrodzkiego, 28-letniego szlachcica z Kraju Zachodniego. Podobnie postąpił podczas wspólnej zabawy zesłańców w podmiejskim lasku. Uznano, że miarka się przebrała i natychmiast po zakończonej zabawie w obecności M. Żaby do mieszkania W. Brewczyńskiego weszła czwórka zesłańców wraz z L. Skrodzkim. Trójka zesłańców obezwładniła szlachcica, natomiast L. Skrodzki $\mathrm{w}$ imieniu obrażanej żony wychłostał go rózgami ${ }^{19}$.

Inna sprawa dotyczyła Henryka Hryncewicza, 39-letniego szlachcica z Królestwa Polskiego i 38-letniego Aleksandra Korfa, szlachcica z guberni kijowskiej. Obydwaj zesłańcy, jak można przypuszczać, otrzymywali spore kwoty pieniężne z domu, jednakże uchylali się od wnoszenia jakichkolwiek opłat do wspólnej kasy. W związku z tym doszło do najścia na ich mieszkanie i wymuszono od nich wpłacanie składki na ogólne potrzeby Towarzystwa Pomocy Wzajemnej.

Michał Żaba miał na sumieniu jeszcze jedno przestępstwo. Otóż w czasie rewizji znaleziono u niego wiersz zatytułowany Członkom Towarzystwa Wzajemnej Pomocy (zob. Aneks). M. Żaba tłumaczył się, że jest to wiersz Tomasza Zana, a przepisał go specjalnie dla niego inny zesłaniec, a mianowicie Antoni Jewcichiewicz ${ }^{20}$, o którym, jak do tej pory, nic nie ustaliliśmy. M. Żaba podczas śledztwa przeprowadzonego 22 stycznia 1867 r. dodał, że A. Jewcichiewicz zmarł jesienią 1866 r.

Wyjaśnił też komisji, że prosił go o przepisanie tego wiersza, bo nie miał żadnego utworu Tomasza Zana, a tak w ogóle to nie podziela zawartego w nim przesłania. Komisja uznała, że jest to wiersz T. Zana,

${ }^{19}$ Opinie na temat skali wymierzonej kary były bardzo rozbieżne. W jednych dokumentach zaznaczono, że L. Skrodzki ukarał W. Brewczyńskiego, uderzając tylko 10 razy rózgami, a w innych, że aż 100 razy.

${ }_{20}$ Nie wydaje się, że zamieszczony w Aneksie wiersz jest autorstwa T. Zana. Prawdopodobnie jego autorem jest A. Jewcichiewicz. 
jednakże nie uwierzyła w oświadczenie M. Żaby, że nie podziela on zawartych w wierszu myśli.

Jak wpłynęło to śledztwo na dalsze losy polskiej diaspory w Kurganie? Na to pytanie na tym etapie badań nie jesteśmy w stanie odpowiedzieć. Najwięcej wiemy na temat losów głównego winowajcy, czyli Michała Żaby. Śledczy postanowili wtrącić go do kurgańskiego więzienia i powiadomić o swej decyzji generała-gubernatora zachodniej Syberii. Z dostępnych materiałów wynika, że w więzieniu był krótko, bowiem jeszcze tego samego roku został przeniesiony do Ust-Kamienogorska i przez jakiś czas przebywał w Semipałatyńsku. Natomiast od lipca 1870 r. do czerwca 1872 r. - w Cariewokokszajskie w guberni kazańskiej. W maju 1871 r. został uwolniony od nadzoru policyjnego ${ }^{21}$, co jednakże nie oznaczało, że mógł wrócić $\mathrm{w}$ rodzinne strony. Zgodnie $\mathrm{z}$ istniejącymi przepisami wolno mu było osiedlić się na terytorium Imperium Rosyjskiego, ale z wyjątkiem stolic i miast gubernialnych. Nie pozwolono mu też powrócić ani na Litwę, ani do Królestwa Polskiego. Michał Żaba miał ponoć zamiar udać się do Wierchoturie (gubernia permska), gdzie przebywał na zesłaniu jego brat Kasper. Ale czy tam dotarł, to już trudno ustalić. Z późniejszych dokumentów wiadomo, że osiedlił się w Aleksandrowskim Żelaznym Zawodzie w obwodzie solikamskim, w guberni permskiej. Z raportów policyjnych wynika, że sprawował się tam dobrze i niewykluczone, że prowadził prywatną praktykę lekarską.

W 1880 r. zmarł jego ojciec i wówczas 76-letnia matka wystąpiła do Michaiła Loris-Melikowa, ministra spraw wewnętrznych, z prośbą o umożliwienie Michałowi przyjazdu do rodzinnego domu w celu notarialnego uregulowania sprawy podziału majątku Szo [sic] między rodzeństwem. M. Loris-Melikow zwrócił się o opinię do gubernatora wileńskiego, kowieńskiego i grodzieńskiego, który nie widział przeszkód, by Michał Żaba zjechał w rodzinne strony na czas uregulowania spraw majątkowych. Jednakże nie wiadomo, jak sprawa się zakończyła ${ }^{22}$.

Ze skąpych materiałów śledczych można wnosić, że pewna niewielka grupa Polaków spośród 160-osobowej zbiorowości została rozesłana do różnych miejscowości guberni tobolskiej. Można też zakładać, że niektórych objęły amnestie z lat 1866-1867 i wrócili w rodzinne strony, ale chyba nie było ich zbyt wielu, bowiem oba akty ułaskawienia obejmowały zesłańców wybiórczo ${ }^{23}$. Do ustalenia liczebności polskiej

21 Государственный Архив Российской Федераци, Ф. 109, 1-я экспедиция, Оп. 43, A. 92, Л. 29.

22 Ibidem, 1. 31-33.

23 Szerzej por.: H. Skok, Polacy nad Bajkałem 1863-1883, Warszawa 1974, s. 302-304. 
diaspory w Kurganie po 1867 r. i warunków jej życia mogłyby się przysłużyć pamiętniki. Mało prawdopodobne jest, by nikt spośród tak licznej grupy nie zostawił żadnych wspomnień. Być może leżą gdzieś na półce w jednej z polskich lub ukraińskich czy wileńskich bibliotek i kiedyś trafią w ręce historyków.

Jak wspomniano, sprawą pobytu polskich zesłańców postyczniowych w Kurganie zainteresował się już w latach sześćdziesiątych XX w. S.F. Kowal w aspekcie tzw. współpracy rewolucyjnej polsko-rosyjskiej. Trudno było tej współpracy dopatrzyć się komisji śledczej, ale na podstawie jej materiałów można sądzić, że relacje zesłanych uczestników powstania styczniowego z mieszkańcami i władzami miasta, zwłaszcza z horodniczym Awenirowiczem Karpińskim, układały się na zasadzie wzajemnego zrozumienia i poszanowania. Natomiast założenie Towarzystwa Pomocy Wzajemnej w Kurganie można by uznać za próbę odrodzenia idei tzw. Ogółów z czasów zsyłki z okresu międzypowstaniowego ${ }^{24}$.

\title{
ANEKS
}

\section{CZŁONKOM TOWARZYSTWA WZAJEMNEJ POMOCY ${ }^{25}$}

\author{
„Niech Bóg poszczęści” mawiali ojcowie \\ Początkom prawnej a szlachetnej pracy; \\ I ja też powiem: „Szczęść Boże panowie \\ I dług swój teraz chociaż tem zapłacę... \\ Śród zim i lodów, w krainie pohańców ${ }^{26}$, \\ Gdzie tyran zgasić nasz ogień się wadzi, \\ Gdzie wszystko ostygnie, prócz serca wygnańców \\ I ludzie tylko snu wiecznemu radzi - \\ Wy jako wierni synowie ojczyzny \\ $\mathrm{Z}$ mężem, co godzien uznania, na czele \\ Nie znając czaszy snu zdradnej trucizny \\ Dążycie $\mathrm{K}^{\prime 27}$ czynom - działacie o! wiele... \\ Tu dzikie bracia! i ziemia i naród, \\ Tu lód tchnie z serca każdego mieszkańca,
}

${ }^{24}$ Por. W. Śliwowska, J. Trynkowski, "Ogóty” - organizacje samopomocowe polskich zestańców we Wschodniej Syberii w l. 40. i 50. XIX w., w: Życie jest wszędzie... Bсюов жизнь... Ruchy społeczne w Polsce i Rosji do II wojny światowej, red. A. Brus, Warszawa 2005, s. 147-182.

${ }_{25}$ ГИАОО, Ф. З, Оп. 6, Д. 7921, А. 733-734.

26 W krainie pogańców, pogan.

27 Prawidłowo: ku czynom. 
Tu obcy cnoty - szlachetności zaród

I grób współczucia tutaj dla wygnańca -

To wzniosły, pierwszy co myśl tę zaszczepił,

By wspólną ręką nieść ulgę niedoli,

To dzielny, ktokolwiek myśl czynem okrzepił

I balsam niesie na ranę, co boli.

I brat z wygnania, i ziomek tam z kraju

I każdy, kiedy gdzie o was się dowie,

Uzna szlachetność w szlachetnym zwyczaju

I: dzielni, dzielni mężowie to! - powie;

Bo ciężko bracia! pod jarzmem przemocy

Gdy nędzy ciężka dłoń kogo przytłacza -

I dzielny, co wtedy z ręką pomocy

Spieszy i krzepi biedaka - tułacza.

Więc cześć wam mili - ten piękny trud - święty

W jedności świętej brata różne części -

I niebem dawno tam pewnie przeklęty,

Kto wam nie powie: „Niechaj Bóg poszczęści!”

Tułacz $^{28}$, Kurgan, 10 listopada [1]864

\section{BIBLIOGRAFIA (REFERENCES)}

\section{Źródła archiwalne}

Gosudarstvennyj Arkhiv Rossijskoj Federatsii (Государственный Архив Российской Федерации):

Ф. 109, 1-я экспедиция, Оп. 43, Д. 92.

Gosudarstvennyj Istoricheskij Arkhiv Omskoj Oblasti (Государственный Исторический Архив Омской Области):

Ф. 3, Оп. 4, Д. 6293.

Ф. 3, Оп. 6, Д. 9079.

Ф. 3, Оп. 6, Д. 7921, t. 1-3.

Gosudarstvennoe uchrezhdenie Tyumenskoj Oblasti «Gosudarstvennyj arkhiv v gorode Tobol'ske» (Государственное учереждение Тюменской Области «Государственный архив в городе Тобольске»)

Ф. И152, Оп. 34, Д. 516; Оп. 36, Д. 178.

„Kraj” 1890, 17.

28 Pod pseudonimem „Tułacz” być może kryje się A. Jewcichiewicz, o którym M. Żaba wspominał w zeznaniach, że zmarł w Kurganie jesienią 1866 r. 


\section{Opracowania}

Koval' S.F., Rewolyutsionnaya deyatel'nost' pol'skikh politicheskikh ssyl'nykh v Sibiri v 60-e gg. XIX v., w: Ékonomicheskoe i obshchestvenno-politicheskoe razvitie Sibiri v 1861-1917 gg, Novosibirsk 1965.

Koval' S.F., Za pravdu i volyu. K stoletiyu vosstaniya politicheskikh ssyl'nykh v Sibiri v 1866 g., Irkutsk 1966.

Mulina S.A., Kontakty ssyl'nykh uchastnikov vosstaniya 1863 goda s istoricheskoj rodinoj (na primere korrespondentsii Mikhaila Zhaby i Ėduarda Radvanskogo), w: Polskie dziewiętnastowieczne pamiętniki i listy z Ziem Zabranych - rola i miejsce w badaniach historycznych, red. W. Caban, L. Michalska-Bracha, Warszawa 2017.

Mulina S.A., Migranty ponevole: adaptatsiya ssyl'nykh uchastnikov Pol'skogo vosstaniya 1863 goda v Zapadnoj Sibiri, Sankt Peterburg 2012.

Nowiński F., Dekabryści z Syberii Zachodniej w literaturze rosyjskiej i polskiej, relacje z Polakami, w: Pol'skie ssyl'nye v Sibiri vo vtoroj polovine XVIII - nachale XX veka v vospriyatii rossijskoj administratsii, pereselentsev $i$ korennykh narodov Sibiri. Sbornik nauchnykh trudov, red. S.A. Mulina, Omsk 2015.

Perminova S.A. (Mulina S.A.), Vzaimootnosheniya pol'skikh ssyl'nykh s zhitelyami Sibiri (po materialam perepiski M. O. Zhaba), w: Polska a Syberia. Spotkanie dwóch światów. Materiaty $z$ konferencji naukowej, red. M. Blomberg, Łodź 2001.

Remnev A.V., Tobol'skij gubernator A.I. Despot-Zenovich, w: Tare 400 let, Omsk 1994.

Skok H., Polacy nad Bajkałem 1863-1883, Warszawa 1974.

Śliwowska W., Zesłańcy polscy w Imperium Rosyjskim w pierwszej połowie XIX wieku, Warszawa 1998.

Śliwowska W., Trynkowski J., "Ogóty” - organizacje samopomocowe polskich zesłańców we Wschodniej Syberii w l. 40. i 50. XIX w., w: Życie jest wszędzie... Vsyudy zhizn'... Ruchy społeczne w Polsce i Rosji do II wojny światowej, red. A. Brus, Warszawa 2005.

Tershukova E.V., Ssyl'nye polyaki v g. Kurgane v pervoj polovine XIX veka, http://www.kurgangen.ru/local-finding/Poles\%20in\%20Zaurali/Poland\%20in\%20Kurgan\%20III/ [dostęp: 13 I 2017].

Wójcik Z., Aleksander Despota(!)-Zenowicz w oczach zestańców, w: Pol'skie ssyl'nye v Sibiri vo vtoroj polovine XVIII - nachale XX veka v vospriyatii rossijskoj administratsii, pereselentsev $i$ korennykh narodov Sibiri. Sbornik nauchnykh trudov, red. S.A. Mulina, Omsk 2015.

\section{Strona internetowa}

http://www.kurgangen.ru/photos/thumbnails.php?album=290 [dostęp: 10 VI 2017].

\section{ABSTRACT}

After the defeat of the January Uprising, a hundred dozen of young Poles, mainly from the area of Lithuania, were exiled to Kurgan. The city authorities were not able to provide support for so many people. Most of the exiles did not receive government benefits. Only those who received money from their families were in a good position. In this situation, the Poles founded a "society against hunger and cold", which later assumed the name of the Society for Mutual Assistance. The main purpose was to collect cash to help those who did not receive any financial help from home. The Society for Mutual Assistance had its own regulations, which forbade, among others, drinking alcohol, playing cards, indulging in any gambling, maintaining relationships with promiscuous women and most importantly marrying Russian women.

The activities of the Society for Mutual Assistance were treated with indulgence by Mikhail Avenirovich Karpinski, the Mayor of Kurgan, who came to conclusion that the 
deportees engaged in their own organization would abide by the adopted regulations and thus there would be no misunderstandings between the Poles and the residents of Kurgan. It seems that the 27-year-old Michał Żaba, a graduate of the Medical Department of the Moscow State University, could have influenced M. Avenirovich Karpinski's opinion.

Inhabitants of Kurgan began to submit denunciations, at first of M. Avenirovich Karpinski's indulgent treatment of Poles, and then levelling similar accusations at the governor of Tobol, Aleksandr Ivanovich Despot-Zenovich. In the end, the case was handed over to the general-governor of West Siberia Aleksandr Petrovich Khrushchev, and so an investigation began in 1867. Among the exiles, Michał Żaba suffered the most as he was not only found guilty of establishing the Society for Mutual Assistance, but also accused of making attempts to establish such organizations in Ishim, or Yalutorovsk. In other words, Żaba was accused of conspiring against the existing order in Russia.

In the 1960s, Soviet historians treated the issue of the Kurgan investigation as an example of Polish-Russian revolutionary cooperation in Siberia. It seems, however, that the establishment of the Society for Mutual Assistance Society should be regarded as an attempt to revive the societies that were created by Polish exiles in Siberia in the period between the November and January Uprisings.

Key words: Siberia, Poles, exiles, Kurgan

\section{NOTA O AUTORACH}

Wiesław Caban - profesor doktor habilitowany, pracuje w Instytucie Historii Uniwersytetu Jana Kochanowskiego w Kielcach. Zajmuje się historią Polski XIX w., a w ostatnich latach dziejami Polaków w Imperium Rosyjskim w XIX w., w tym zesłaniami syberyjskimi. Ostatnio opublikował, m.in. wspólnie z prof. Jerzym Szczepańskim: Jan Witort, O syberyjskim zestaniu i rusyfikacji Żmudzi (Warszawa 2017). E-mail: caban@ujk.edu.pl

Swietłana Anatoljewna Mulina - docent w Państwowym Uniwersytecie im. Fiodora Dostojewskiego w Omsku. Główny nurt jej zainteresowań to dzieje syberyjskiej zsyłki i relacje polsko-rosyjskie w XIX w. Autorka ok. 80 publikacji, m.in. Migranci wbrew swej woli. Adaptacja zestanych powstańców styczniowych na Syberii Zachodniej (Warszawa 2018). E-mail: wiewiorka@mail.ru 